\title{
Tłumaczenie sądowe a ocena wiarygodności zeznań świadka
}

\author{
Katarzyna Liber \\ Uniwersytet Jagielloński \\ kasia.liber@op.pl
}

\begin{abstract}
Streszczenie
W niniejszym artykule przedstawiono psychologiczne i prawnicze kryteria oceny wiarygodności zeznań świadków $w$ kontekście pracy tlumacza $w$ środowisku sadowym, w szczególności $w$ odniesieniu do wierności ttumaczenia i ewentualnego wpływu transformacji na ocenę dowodu osobowego przez sad. Pomimo znaczacego postepu technologii wykorzystywanych $w$ kryminalistyce zeznania nadal sa istotna wskazówka dowodowo-wykrywczq i maja bezpośredni wpływ na orzeczenia sądów. Przesłuchanie jako czynność procesowa przeprowadzana zarówno w postępowaniach karnych, jak i cywilnych, jest złożonym aktem komunikacji interpersonalnej, $w$ trakcie którego ksztaltowane jest subiektywne przekonanie sadu co do szczerości $i$ prawdziwości zeznań, zaś obecność tłumacza jako pośrednika pomiędzy przestuchujacym a przestuchiwanym dodatkowo czynność tę komplikuje. Określenie wartości zeznania zależy od wielu czynników, których tlumacz powinien być świadomy, podobnie jak doniosłości swej roli, jaka odgrywa, uczestniczac w postępowaniu sadowym. W oparciu o dotychczasowa wiedze $i$ przeprowadzone wywiady z polskimi thumaczami przysiegłymi, sformułowano przesłanki do przeprowadzenia pogłębionych badań na temat wptywu strategii ttumacza na ocenę świadka $i$ złożonych przez niego zeznań.
\end{abstract}

Stowa kluczowe: thumaczenie środowiskowe, thumaczenie sadowe, kryteria oceny wiarygodności zeznań, analiza treściowa zeznań, CBCA, SVA, kryterialna analiza danych

\section{Abstract}

Court interpreting and the assessment of witness veracity

The present article presents the psychological and legal criteria for the assessment of the reliability of witness testimony in the context of the work of an interpreter in a court environment, specifically in relation to the accuracy of the interpretation and the possible impact of the transformation on the assessment of the personal evidence by the court. Despite the considerable technological progress in criminology, testimony is still a significant 
evidentiary - investigative indicator and has a direct impact on the court rulings. Questioning as a procedural activity carried out in criminal as well as in civil proceedings, is a comprehensive act of interpersonal communication, in the course of which the subjective conviction of the court as to the honesty and accuracy of the testimony is shaped, and the presence of an interpreter as an intermediary between the questioning party and the party being questioned additionally complicates this action. Indicating the values of the testimony depends on many factors, which the interpreter needs to be aware of, similarly as the importance of the role they play by participating in court proceedings. Based on the knowledge to date, and interviews conducted with Polish sworn interpreters, prerequisites were formed to conduct indepth studies concerning the impact of translator's strategy on the evaluation of the witness and testimonies submitted by them.

Keywords: community interpreting, court interpreting, criteria of testimony veracity assessment, content analysis of testimony, CBCA, SVA, Criteria-Based Content Analysis

\section{Wstęp}

Pojęcie wiarygodności odnosi się do subiektywnego przekonania organu procesowego dotyczącego prawdziwości zeznania i stopnia, w jakim oddaje ono rzeczywisty przebieg zdarzenia, zaś przekonanie to kształtowane jest na podstawie zgromadzonego materiału dowodowego. Klasyfikacja zeznania i określenie jego wartości dowodowej, czyli uznanie relacji świadka za szczerą i prawdziwą ${ }^{1}$, zależy od szeregu czynników, które od lat są przedmiotem zainteresowania psychologii sądowej, w ramach której próbuje się stworzyć zobiektywizowane narzędzie do analizy treściowej zeznań. Testowane empirycznie kryteria psychologiczne, postulowane kryteria prawnicze, ale także nieuświadomione i subiektywne kryteria stosowane przez sędziów, pośrednio lub bezpośrednio decydują o tym, czy to, co powie świadek, będzie miało wpływ na rozstrzygnięcie sądu.

Przesłuchanie jako czynność procesowa dodatkowo komplikuje się, gdy w komunikacji między sądem a obcojęzycznym świadkiem musi uczestniczyć tłumacz. Idealny model tłumacza środowiskowego zakłada, że jest on wyłącznie neutralnym pośrednikiem, który przekazuje informacje bez żadnych modyfikacji jakościowych i ilościowych. Zarówno polska Ustawa o zawodzie tłumacza przysięgłego, jak i Kodeks tłumacza przysięgłego, nakładają na tłumacza obowiązek dochowania wierności i bezstronności w toku całego postępowania. Zasadniczym pytaniem jest jednak to, czy tłumacze istotnie zdają sobie sprawę, że tłumaczenie może mieć wpływ na ocenę wiarygodności zeznania, oraz czy są świadomi, jak doniosłą rolę odgrywają w środowisku sądowym? 
W niniejszym artykule przedstawiono kryteria psychologicznej i prawniczej oceny zeznań w kontekście jakości pracy tłumacza sądowego i wymagań, jakie powinno się stawiać thumaczom, aby faktycznie pełnili oni funkcję bezstronnych i wiernych pośredników językowych.

\section{Rola świadka w procesie karnym}

Świadkiem, w sensie faktycznym, jest osoba fizyczna dysponująca określonymi informacjami, które dotyczą prowadzonego postępowanie - w myśl art. 40 § 1 pkt 4 Kodeksu postępowania karnego (tzw. „świadek czynu”) ${ }^{2}$. Świadkiem, w sensie formalnym, jest również osoba wezwana przez organ procesowy do złożenia zeznań ze względu na domniemaną wiedzę, która mogłaby być istotna dla sprawy. Jak pokazuje praktyka, przesłuchanie jest najczęściej wykonywaną czynnością procesową (Ludwin 2015: 118), zaś dowody osobowe, w tym zeznania świadków, pełnią niezwykle ważną rolę w polskim procesie karnym i mimo znaczącego postępu technologii, przede wszystkim technologii wykorzystywanych $\mathrm{w}$ kryminalistyce, zeznania nadal są istotną wskazówką dowodowo-wykrywczą na etapie postępowania przygotowawczego (Niezgoda 2007: 76), zaś w postępowaniu sądowym nierzadko mają bezpośredni wpływ na orzeczenie sądu.

Na przebieg przesłuchania wpływają liczne czynniki związane z wzajemną percepcją i oceną przesłuchującego i przesłuchiwanego: ich postawy, motywacja, stan psychiczny, oczekiwania i cele (Niezgoda 2007: 76). Jeżeli w przesłuchaniu uczestniczy tłumacz, ów specyficzny proces komunikacji interpersonalnej dodatkowo się komplikuje, bowiem oprócz wzajemnego oddziaływania dwóch stron, dochodzą indywidualne czynniki osobowościowe i motywacyjne tłumacza, przez którego, niczym przez filtr, przekazywane są wszystkie informacje.

Problemy związane z użytecznością zeznań i wiarygodnością dowodów osobowych dotyczą dwóch aspektów: 1) procesu spostrzegania, zapamiętywania, przechowania śladów pamięciowych i ich odtwarzania, a także 2) prawdomówności świadka. Pierwszy wskazany problem dotyczy ograniczeń w spostrzeganiu oraz wpływu czynników zewnętrznych i wewnętrznych na zdolności poznawcze świadka, tj. sposobu, w jaki spostrzegał on dane zdarzenie, możliwości prawidłowego zapisywania i przechowywania śladów pamięciowych bez uszczerbku dla ich jakości i objętości (co wbrew obiegowej opinii wcale nie jest ani proste, ani oczywiste) i w końcu - możliwości, względnie umiejętności prawidłowego odtworzenia śladu pamięciowego w sposób, który będzie najwierniej odpowiadał prawdzie. Od lat toczy się 
dyskusja na temat tego, na ile świadek jest w stanie „obiektywnie” spostrzegać dane zdarzenie, na ile może prawidłowo je zapamiętać i zrelacjonować po upływie określonego czasu, bowiem proces spostrzegania warunkuje szereg czynników zewnętrznych, takich jak czas spostrzegania, odległość od obiektu, jego oświetlenie i ruch, a także czynników osobowych, określanych mianem „czynników anatomiczno-fizjologicznych”, do których zaliczyć można wiek, stopień zmęczenia, wadę wzroku, wadę słuchu, upojenie alkoholem, stan zdrowia, czy wreszcie stany emocjonalne obserwatora (zob. Stawiarski 2008). Z kolei ludzka pamięć nie jest „narzędziem” doskonałym, o czym możemy się przekonać w codziennej konfrontacji wspomnień, gdy dwie osoby uczestniczące w zdarzeniu zapamiętały je zgoła odmiennie. Ślady pamięciowe podlegają procesom stereotypizacji (inaczej prototypizacji, która oznacza dopasowywanie wspomnień do określonych schematów typowych i odchodzenie od rzeczywistego przebiegu zdarzenia) i stopniowemu zacieraniu (zob. Najder 1992: 126 i nast.). Pamięć jest na tyle plastyczna, że możliwe jest również wprowadzenie tzw. „fałszywych wspomnień” zdarzeń, które nigdy nie miały miejsca (Maciaszek 2013). Dlatego świadkowie, mimo szczerej motywacji do złożenia prawdziwych zeznań, często mylą się w swoich relacjach i przekazują nieprawdziwe informacje.

Drugi problem - prawdomówność świadka, jest przedmiotem zainteresowania prawników, psychologów oraz - w mniejszym stopniu - językoznawców, którzy od lat próbują stworzyć metody skutecznego wydobywania informacji w toku postępowania (metody przesłuchania, wykorzystanie technologii) i trafnego oceniania wiarygodności zeznań. Wskaźników prawdomówności badacze poszukują zarówno w warstwie werbalnej, jak i niewerbalnej. Na ten moment, mimo powszechnego przekonania, że mowa ciała „zdradza więcej niż słowa", nie udało się wyodrębnić jasnych i bezsprzecznych kryteriów niewerbalnych, których trafność diagnostyczna była wysoka i które byłyby użyteczne także w praktyce sądowej. Stąd rosnące zainteresowanie warstwą językową i zintensyfikowane prace nad stworzeniem kryteriów analizy treściowej, które zostaną omówione w dalszej części artykułu.

Proces przesłuchania jest sam w sobie niezwykle złożony i trudny, zaś wprowadzenie do niego dodatkowego elementu, jakim jest pośrednictwo tłumacza, wymaga od przesłuchującego i tłumacza niezwykłej czujności, staranności i świadomości: przesłuchujący powinien wiedzieć, jak należy współpracować z tłumaczem, na czym polega proces tłumaczenia i z jakimi ograniczeniami się wiąże, z kolei tłumacz powinien znać zasady i sens prowadzenia przesłuchania oraz być świadom kryteriów oceny wiarygodności zeznań świadka. 


\section{Kryteria psychologiczne - analiza treściowa zeznań}

Podstawowym założeniem leżącym u podstaw psychologicznej analizy treściowej jest tzw. hipoteza Undeutscha, w myśl której zeznania oparte na prawdziwych zdarzeniach i doświadczeniach świadka różnią się jakościowo i ilościowo od zeznań sfabrykowanych (Marten 1990: 197). Udo Undeutsch przyjął pięć grup kryteriów:

1. historia zeznania pojmowana jako stałość relacji (utrzymywanie ogólnej linii narracyjnej),

2. cechy czynności relacjonowania, na którą składa się: język i sprawność wypowiedzi oraz jej wewnętrzna spójność,

3. struktura osobowości i stopień rozwoju świadka,

4. motywacja świadka do składania zeznań (głównie stopień powiązania ze sprawą),

5. cechy zawartości zeznania, na które składają się a) pierwotne kryteria oceny (oryginalność, liczba szczegółów, powiązanie opisów z sytuacjami życiowymi, konkretność, homogeniczność) oraz b) wtórne kryteria oceny (zawartość treściowa, stopień zgodności z innymi ustaleniami lub z tzw. prawdami oczywistymi (Marten 1990: 198).

Zintensyfikowane prace psychologów sądowych i kolejne ustalenia $\mathrm{w}$ tej dziedzinie zaowocowały stworzeniem konkretnych technik oceny zeznań. Najbardziej znaną i godną omówienia jest technika Statement Validity Assessment autorstwa Maksa Stellera i Güntera Köhnkena, która zyskała aprobatę sądów w Niemczech, a następnie w Stanach Zjednoczonych, Kanadzie i wielu krajach Europy. Na technikę składa się 9 kroków postępowania ${ }^{3}$, które w literaturze przedmiotu często upraszcza się do trzech: 1) ustrukturalizowany wywiad, 2) kryterialna analiza danych (Criteria Based Content Analysis - CBCA), 3) ocena wyników CBCA za pomocą pytań kontrolnych (Kontrolna Lista Wiarygodności) (Vrij 2009: 111). Z perspektywy thumacza najważniejsza jest kryterialna analiza danych $\mathrm{z}$ wykorzystaniem 19 kryteriów CBCA. Kryteria te podzielone są na cztery grupy: 1) cechy ogólne, 2) konkretne treści, 3) treści związane z motywacją i 4) elementy charakteryzujące przestępstwo.

1) Cechy ogólne

1. Struktura logiczna - kryterium uważa się za spełnione, jeśli relacja świadka jest spójna i logiczna, a poszczególne jej części nie są ze sobą sprzeczne. 
2. Wypowiedź pozbawiona struktury - kryterium występuje wtedy, gdy informacja jest rozproszona po całej wypowiedzi, zaś sama relacja nie jest ustrukturyzowana i uporządkowana chronologicznie. Brak struktury charakteryzuje przede wszystkim relacje osób będących pod wpływem silnych emocji, które nie potrafią ,zebrać myśli” i przedstawiają zdarzenie w sposób chaotyczny.

3. Liczba szczegółów - kryterium jest spełnione, jeśli relacja świadka jest bogata w różne detale i opisy dotyczące miejsca, czasu, ludzi, zdarzeń i przedmiotów.

2) Konkretne treści

4. Osadzenie $w$ kontekście - kryterium występuje, jeśli świadek umiejscawia zdarzenie $\mathrm{w}$ czasie i miejscu, zaś opisywane działania powiązane są z jego codziennymi czynnościami lub zwyczajami (np. „widziałam to, gdy stałam na balkonie i paliłam papierosa - gdy jest ciepło zawsze palę na zewnątrz, żeby nie śmierdziało w domu").

5. Opisy interakcji - kryterium jest spełnione, jeśli świadek w swojej relacji przytacza interakcje, w których uczestniczy co najmniej oskarżony i świadek, oraz jeśli przedstawiona interakcja składa się przynajmniej z trzech części: akcja reakcja-akcja (np. ,„powiedziałem mu, żeby się odczepił, na co on mnie odepchnął, a ja wtedy rzuciłem w niego wazonem").

6. Odtworzenie mowy - z tym kryterium mamy do czynienia, gdy świadek odtwarza fragment konwersacji w oryginalnym brzmieniu lub przynajmniej wypowiedzi jednej osoby (np. „mówię mu: 'zostaw go w spokoju', a on mi na to: 'odwal się”’). 7. Nieoczekiwane komplikacje podczas zdarzenia - kryterium jest spełnione, jeśli świadek przytacza dość nieoczekiwane elementy zdarzenia lub zaistniałe komplikacje (np. pękła przednia szyba w samochodzie sprawcy, gdy ten zamknął drzwi).

8. Niezwykłe szczegóły - kryterium występuje, jeśli świadek przytacza unikatowe szczegóły dotyczące ludzi, przedmiotów lub wydarzeń, które mogą mieć znaczenie dla sprawy (np. świadek opisuje tatuaż sprawcy).

9. Zbędne szczegóły - kryterium jest spełnione, jeśli świadek przytacza szczegóły, które są związane ze sprawą, ale nie mają wpływu na oskarżenie (np. świadek opisuje, jak zachowywał się pies sprawcy). 
10. Niezrozumienie dokładnie opisanych szczegółów - kryterium występuje wtedy, gdy świadek podaje konkretne informacje, choć ich nie rozumie. Kryterium to sprawdza się głównie u małoletnich świadków (np. dziecko opisuje zachowanie seksualne dorosłego, jednak nie rozumie jego znaczenia).

11. Powiązane skojarzenia zewnętrzne - kryterium występuje, gdy świadek opowiada o zdarzeniach, które nie są częścią przestępstwa, jednak są z nim związane (np. przytaczanie rozmowy sprawcy z innym uczestnikiem zdarzenia).

12. Opisy subiektywnego stanu mentalnego - kryterium jest spełnione, jeśli świadek opisuje swoje uczucia lub myśli, które towarzyszyły mu podczas zdarzenia.

13. Przypisywanie sprawcy okréślonego stanu mentalnego - kryterium występuje wtedy, gdy świadek opisuje motywy, uczucia lub myśli sprawcy w czasie zdarzenia.

3) Treści związane z motywacją

14. Spontaniczne poprawki - kryterium jest spełnione, gdy świadek, bez zaangażowania przesłuchującego, wprowadza poprawki lub dodatkowe informacje do tego, co uprzednio zrelacjonował.

15. Przyznawanie się do luk $w$ pamięci - kryterium występuje, gdy świadek spontanicznie przyznaje, że czegoś nie pamięta („nie wiem”, „nie pamiętam”, „zapomniałem”).

16. Poddawanie $w$ watpliwość własnych zeznań - kryterium występuje, gdy świadek wyraża zaniepokojenie, czy jego relacja brzmi prawdopodobnie i czy nie wydaje się być błędna (np. ,... to było na pewno głupie z mojej strony”, ,wiem, że brzmi to nieprawdopodobnie, ale...”).

17. Autodeprecjacja - kryterium jest spełnione, jeśli świadek przytacza niekorzystne dla siebie informacje, które mają charakter samooskarżenia.

18. Usprawiedliwianie sprawcy - kryterium występuje, gdy świadek wyraża przychylność wobec sprawcy, tzn. usprawiedliwia go lub nie obwinia.

4) Elementy charakteryzujące przestępstwo

19. Szczegółowy opis przestępstwa - kryterium uważa się za spełnione, jeśli świadek opisuje zdarzenie w sposób zgodny z tym, jak zdaniem specjalistów przebiegają tego typu zdarzenia (opracowanie na podstawie: Vrij 2009 i Wojciechowski 2016). 
SVA nie wyczerpuje wszystkich możliwych kryteriów. Nie jest zresztą jedyną techniką oceny wiarygodności zeznań stosowaną przez psychologów. W Instytucie Psychologii Uniwersytetu Śląskiego w Katowicach stworzono technikę MASAM (Model Wielozmiennowej Analizy Zeznań Świadków Dorostych - Multivariable Adults' Statements Assesment Model, autorstwa Bartosza W. Wojciechowskiego), która obejmuje 21 kryteriów analizowanych z uwzględnieniem cech obiektu/zdarzenia, osoby spostrzegającej i cech przesłuchania ${ }^{4}$. Trwają również badania nad weryfikacją trafności diagnostycznej dodatkowych pięciu kryteriów zaproponowanych przez Eberhard Höfera, Gönter Köhnkena, Reiner Hanewinkel i Christine Bruhn w niepublikowanym raporcie dla Uniwersytetu w Kilonii: styl sprawozdawczy (reporting style - rozumiany jako rozwlekła wypowiedź, w której świadek opisuje aspekty niezwiązane z zadanym mu pytaniem), powtórzenia (repetitions - definiuje się jako opisane uprzednio elementy wypowiedzi, które powtarzane są bez żadnych dodatkowych szczegółów), wtrącenia (clichés - definiowane jako wypowiedzi, wyrażenia lub słowa, które nie są niezbędne dla opisu, a które wprowadzają opóźnienie w wypowiedzi), uzasadnianie luk pamięciowych (providing reasons for lack of memory - występuje w sytuacji, gdy świadek spontanicznie podaje przyczynę, dla której nie jest w stanie opisać danej rzeczy lub udzielić bardziej szczegółowych informacji) i wyrażanie niepewności (display insecurities - kryterium występuje, gdy świadek opisuje daną rzecz/sytuację, lecz wyraża niepewność, czy jego opis jest poprawny), które mogłyby być wykorzystane w celu uzupełnienia lub modyfikacji arkusza SVA (zob. Köhnken, Schimossek, Aschermann i Höfer 1995; Amado, Arce, Farina, Vilarino 2016; por. Liber 2017)

Odnosząc powyższe kryteria do pracy tłumacza w warunkach sądowych, należy podkreślić, iż z perspektywy psychologicznej analizy treściowej zeznań każdy szczegół, nawet pozornie nieistotny dla osoby postronnej, może mieć znaczenie dla oceny wiarygodności świadka. Psychologowie sądowi przywiązują wagę do wszystkich przytoczonych przez świadka opisów, do sposobu przedstawienia zdarzenia i relacjonowania rozmów uczestników, do konstrukcji wypowiedzi świadka, opisów na pozór nieistotnych lub niezwiązanych ze sprawą, informacji dotyczących emocji i stanów mentalnych świadka i oskarżonego, informacji podawanych w sposób niejasny lub niezrozumiały, wyrażeń dotyczących niepewności świadka lub jego zaniepokojenia związanego z oceną jego zeznania, powiązania opisów zdarzenia z czynnikami zewnętrznymi itd. Pominięcie przez tłumacza pewnych elementów relacji źródłowej ostatecznie może mieć wpływ na ocenę wiarygodności świadka. 


\section{Kryteria prawnicze - ocena sędziów}

Jak zauważa Ewa Gruza, poznanie zdarzenia przestępczego przez sąd jest poznaniem pośrednim, czyli poprzez dowody, dlatego sądy, mimo świadomości tego, że zeznania mogą być obciążone sporym błędem, nadal darzą świadków sporym zaufaniem, bowiem zeznania pozwalają zredukować „ogniwa poznania” do minimum (Gruza 2014: 71). Wszystkie dowody, w tym dowody osobowe, czyli zeznania świadka, zgodnie z art. 7 Kodeksu postępowania karnego oraz art. 233 Kodeksu postępowanie cywilnego, podlegają zasadzie swobodnej oceny sądu (,organy postępowania kształtują swe przekonanie na podstawie wszystkich przeprowadzonych dowodów, ocenianych swobodnie z uwzględnieniem zasad prawidłowego rozumowania oraz wskazań wiedzy i doświadczenia życiowego”, art. 7 k.p.k; ,sąd ocenia wiarogodność i moc dowodów według własnego przekonania, na podstawie wszechstronnego rozważenia zebranego materiału", art. 233 § 1 k.p.c.). Jak pokazuje dotychczasowa linia orzecznicza, naczelną zasadą organizującą wiedzę sędziów i warunkującą ocenę wiarygodności zeznań, są reguły logiki, czyli rozumowanie dedukcyjne i indukcyjne. Jak możemy przeczytać w wyroku Sądu Najwyższego (postanowienie SN z 15 lutego 2000 roku, III CKN 1049/99, LEX nr 51627):

Przyjmuje się (...), że ramy swobodnej oceny dowodów muszą być zakreślone wymaganiami prawa procesowego, doświadczenia życiowego, regułami logicznego myślenia oraz pewnego poziomu świadomości prawnej ${ }^{5}$, według których sąd $\mathrm{w}$ sposób bezstronny, racjonalny i wszechstronny rozważa materiał dowodowy jako całość, dokonuje wyboru określonych środków dowodowych i ważąc ich moc oraz wiarygodność odnosi je do pozostałego materiału dowodowego.

Kryteria logiczne i ,życiowe”, w ocenie Sądu Apelacyjnego w Szczecinie, przeważają nawet nad faktem, że świadek pozostaje w bliskiej relacji ze stroną (wyrok SA w Szczecinie z 21 marca 2013 roku, I ACa 4/13, LEX nr 1344193):

Ocena zeznań świadków nie może ograniczać się do rodzaju stosunków łączących świadka ze stroną, ale powinna opierać się na zestawieniu treści zeznań z pozostałymi dowodami (...), po rozważeniu wynikłych sprzeczności w świetle zasad logiki i doświadczenia życiowego.

Podobną opinię przeczytać możemy w wyroku Sądu Apelacyjnego w Warszawie 14 sierpnia 2012 roku (I ACa 37/12, LEX nr 1238219): 
Zeznania takiego świadka są oceniane z uwzględnieniem wszystkich okoliczności, w tym również stosunku, w jakim pozostaje on do każdej ze stron, ale ponadto - $\mathbf{z}$ uwzględnieniem jego cech osobistych, relacji między treścią jego zeznań a innymi dowodami w sprawie itd.

Jak zauważa Marcin Maciejski, stosowanie reguł logicznych nie daje żadnej gwarancji dotarcia do prawdy, jednak ich niestosowanie zawsze prowadzi do błędu (Maciejski 2009: 141).

W ocenie wiarygodności zeznania przez sąd istotna jest relacja między tym, co mówi świadek, a tym, o czym świadczą inne dowody - jak stwierdził Sąd Najwyższy w wyroku z dnia 5 października 2011 (II UK 43/11, LEX nr 1108484), relacja świadka nie może być $a$ priori uznana za niewiarygodną przez fakt, że stoi w sprzeczności z innymi dowodami. Także w wyroku Sądu Apelacyjnego w Białymstoku z dnia 5 marca 2014 roku (II AUa 1272/13, LEX nr 1451561) czytamy:

[Świadectwo pracy] jako dowód $\mathrm{z}$ dokumentu prywatnego nie ma silniejszej mocy dowodowej, niż dowód z zeznań świadków lub z przesłuchania stron.

W największym uproszczeniu można by powiedzieć, że sąd zwraca uwagę przede wszystkim na to, czy zeznania są logiczne, spójne i konsekwentne. W literaturze przedmiotu wskazuje się cztery podstawowe kryteria oceny wiarygodności zeznań i wartości dowodu osobowego: 1) doświadczenie życiowe, 2) inne źródła wiedzy, 3) poprawność logiczna oraz 4) prawdopodobieństwo wersji (Maciejski 2009: 141). Od sądu oczekuje się również, że nie będzie kierować się emocjami, uprzedzeniami i nie podda się irracjonalnym procesom myślowym. Sąd zobowiązany jest także do samodzielności i niezależności w rozumowaniu i wnioskowaniu w ocenie przeprowadzonych dowodów (Gadomska-Radel 2010: 79).

W literaturze prawniczej sugeruje się, aby w ocenie wiarygodności zeznań reguły logiki stosować z uwzględnieniem następujących warunków:

1) czy świadek wie, z jakimi spostrzeżeniami powinno się wiązać określoną wypowiedź w danym języku?

2) czy proces postrzegania świadka przebiegał prawidłowo (czy nie było dystraktorów/zakłóceń zewnętrznych, środowiskowych lub wewnętrznych wynikających z nieprawidłowego funkcjonowania narządu spostrzegania)?

3) czy świadek prawidłowo rozpoznał źródło spostrzeżeń i dokonał prawidłowej ich syntezy? (Płachta 1984: 158). 
Powyższe wskazuje nam zatem, że sąd w swej ocenie zeznania powinien również uwzględnić inne czynniki i okoliczności, takie jak procesy poznawcze świadka, okoliczności spostrzegania i ich wpływ na zdolność spostrzegania, a także zasoby świadka oraz rodzaj operacji mentalnych dokonywanych w czasie i po spostrzeganiu. Oznacza to, że sąd w swojej ocenie uwzględniać będzie również czynniki psychologiczne.

Maciejski przeprowadził badanie nad jawnymi i ukrytymi kryteriami wiarygodności wykorzystywanymi w praktyce sędziowskiej (Maciejski 2009). W toku analizy wyodrębniono 24 kryteria, którymi posługiwali się sędziowie przy ocenie konkretnych zeznań: 1) treść zeznań co do przedmiotu sprawy, 2) zgodność z innymi dowodami, 3) osobowość świadka, 4) zachowanie świadka, 4) odpowiednia liczba szczegółów, 5) poziom spójności i logiczności, 6) poziom stałości, zmienności, 7) emocjonalność i uczuciowość, 8) powiązanie z oskarżonym, 9) powiązanie z innymi uczestnikami, nastawienie, 10) motywacja, 11) nastawienie, stanowczość, 12) pozycja zawodowa świadka, wykształcenie, spostrzegany poziom sprawności umysłowej, 13) język, budowa, jasność, 14) ilość uzupełnień, 15) spontaniczność, 16) czas, 17) okres latencji, 18) pierwsze wrażenie, 19) komunikacja niewerbalna, 20) pozycja społeczna świadka, tryb życia, karalność, 21) osadzenie w czasie, przestrzeni, 22) okoliczności spostrzegania, 23) opisy interakcji, 24) opinia o świadku w środowisku lokalnym.

Jak pokazują wyniki badania, najważniejszym (najczęściej stosowanym) kryterium jest treść samych zeznań (45,5\% przypadków) oraz liczba podawanych szczegółów (35,5\%). W ocenie sędziowskiej niezwykle ważna jest również zgodność z innymi dowodami (41\%), osobowość świadka (39\%) i jego zachowanie (39\%). Poziom spójności i logiczności jest najważniejszym kryterium w schemacie poznawczym sędziów (35\%). Z kolei kryterium zdecydowanie i stanowczość stosowane było 19,5\% przypadków, emocjonalność i uczuciowość w 29\%, język, budowa i jasność w 16,5\%, zaś liczba uzupetnień w 16\% (zob. Maciejski 2015: 191 i nast.).

Powyższe badanie pokazuje, że częściowo kryteria sędziowskie pokrywają się $\mathrm{z}$ kryteriami przyjętymi w psychologicznej ocenie zeznań (szczegóły, spójność i logiczność, zdecydowanie i stanowczość, język, budowa, jasność, osadzenie w czasie i przestrzeni), tym samym, podobnie jak w przypadku psychologicznych kryteriów oceny wiarygodności, wszelkie transformacje w warstwie językowej wypowiedzi świadka mogą mieć bezpośredni wpływ na sposób jej oceny przez sąd. 


\section{Przesłanki do badań}

Zgodnie z art. 14 Ustawy z dnia 25 listopada 2004 roku o zawodzie tłumacza przysięgłego, tłumacz przysięgły zobowiązany jest do ,wykonywania powierzonych mu zadań ze szczególną starannością i bezstronnością”. Jest to w zasadzie jedyna wzmianka, co do jakości podejmowanych przez tłumacza czynności. W Kodeksie tłumacza przysięgłego znajdujemy zalecenie: „ttumacz przysięgły jest zobowiązany do wykonywania powierzonego mu tłumaczenia ze szczególną starannością, zachowując wierność wobec tekstu źródłowego zgodnie z zasadami sztuki thumaczenia specjalistycznego i formalnoprawnymi zasadami tłumaczenia sądowego i prawniczego, które mogą różnić się od nieprofesjonalnych interpretacji zleceniodawców” ( $§ 2$ Kodeksu thumacza przysięgłego) ${ }^{6}$. I choć sama idea wierności tłumaczenia i rzetelności tłumacza wydaje się być bezsporna, problem rodzi się w samej praktyce.

W celu rozeznania, czy istnieje potrzeba przeprowadzenia szczegółowych badań nad ewentualnym wpływem transformacji językowych $\mathrm{w}$ tłumaczeniu sądowym na ocenę wiarygodności zeznań, przeprowadzono wywiady nieustrukturalizowane z 32 tłumaczami przysięgłymi zaprzysiężonymi przez Ministerstwo Sprawiedliwości RP, dotyczące dostrzeganych przez nich trudności i problemów w zakresie jakości tłumaczeń sądowych, a także strategii tłumaczeniowych, które mogłyby mieć wpływ na odbiór zeznań świadka.

W próbie znalazły się osoby w wieku od 38 do 60 lat, z których każda ma minimum 3letni staż w pracy tłumacza przysięgłego. Istotnym kryterium doboru badanych była również częstotliwość udziału w rozprawach sądowych: nie rzadziej niż raz na dwa miesiące. Badani odpowiadali opisowo na pytanie, czy w ich przekonaniu zdarza im się w jakikolwiek zmieniać zeznania świadka w czasie tłumaczenia ustnego (skracać, uzupełniać, porządkować, ugładzać stylistycznie, pomijać elementy zeznania ocenione jako zbędne itp.). Starano się nie sugerować tłumaczom żadnej odpowiedzi, bowiem celem wywiadu było uzyskanie informacji będących refleksją badanych nad ich strategią tłumaczenia. Respondentów pytano również o problemy we współpracy z sądem w kontekście tłumaczenia zeznań świadków, a także o kwalifikacje zawodowe tłumaczy, kontrolę ich pracy i jakość tłumaczeń uwierzytelnionych w Polsce.

\subsection{Opinie thumaczy i dotychczasowe wyniki badań}

Odpowiedzi respondentów (łącznie 32 osoby) podzielono na 4 kategorie zmian:

1) upraszczanie wypowiedzi (pomijanie zbyt wielu szczegółów, pomijanie informacji, które są w ocenie tłumacza mniej istotne, przy czym tłumacze nie byli w stanie wskazać, 
jakie informacje najczęściej zdarza im się pominąć) - zmiany te wskazało 32\% respondentów,

2) porządkowanie relacji świadka lub zmiana porządku wypowiedzi (porządkowanie wypowiedzi chaotycznych, rozpoczynanie thumaczenia od informacji najlepiej zapamiętanych) - zmiany te wskazało $45 \%$ respondentów,

3) zmiana rejestru wypowiedzi świadka (unikanie sformułowań żargonowych, podwyższanie rejestru, usuwanie ,zbędnych” powtórzeń) - zmiany te wskazało 37\% respondentów,

4) zmiana mowy niezależnej na zależną - zmiany te wskazało $42 \%$ respondentów,

5) niesygnalizowanie spontanicznych poprawek świadka (tj. tłumaczenie wyłącznie skorygowanej wypowiedzi bez sygnalizowania, że świadek uzupełnił bądź wprowadził zmiany) - zmiany te wskazało $26 \%$ respondentów.

Z kolei przeprowadzone dotychczas badania (Hale 2004) wskazują na następujące tendencje:

1) tłumacz może mieć wpływ na postrzeganie stopnia pewności świadka w dwojaki sposób:

a) poprzez usuwanie przejawów niepewności świadka - pomijanie w tłumaczeniu zawahań, powtórzeń, pauz w wypowiedzi, westchnień, przejęzyczeń, pomijanie stwierdzeń świadczących o niepewności, niewiedzy, pomijanie/zmiana partykuł epistemicznych lub zmiana czasowników modalnych (to mógł być / to musiał być);

b) poprzez niepewność samego tłumacza, czyli występowanie w tłumaczeniu zawahań, powtórzeń, pauz, zająknięć, westchnień itp.

2) tłumacz może mieć wpływ na sposób postrzegania inteligencji i elokwencji świadka, również w dwojaki sposób:

a) poprzez usuwanie błędów gramatycznych i stylistycznych z wypowiedzi świadka (tzw. ,polerowanie”);

b) poprzez błędy gramatyczne i stylistyczne w tłumaczeniu (zob. Hale 2004).

W eksperymencie przeprowadzonym przez Hale stwierdzono, że ,wypolerowana” stylistycznie wersja zeznania ocenia jest jako bardziej wiarygodna, a świadek uznawany jest za bardziej kompetentnego i inteligentnego (Hale 2004: 173 i nast).

W innych badaniach zaobserwowano tendencję tłumaczy do stosowania bardziej oficjalnego stylu niż w wypowiedzi oryginalnej (zob. Berk-Seligson 1990; Hale 1997) oraz tendencję do 
używania większej liczby zwrotów grzecznościowych, co również przekłada się na sposób spostrzegania świadka przez sąd (zob. Mason, Stuart 2001).

\subsection{Problem kwalifikacji tłumaczy i współpracy z sądem}

W przeprowadzonych wywiadach thumacze proszeni byli o wskazanie warunków okołoprzekładowych, które mogłyby mieć wpływ na jakość tłumaczeń w polskim środowisku sądowym. Na podstawie udzielonych odpowiedzi wyodrębniono dwa zasadnicze problemy:

\section{1) Kwalifikacje tlumaczy i weryfikacja pracy tlumaczy}

Jakość tłumaczeń, w tym tłumaczeń uwierzytelnionych, jest od lat tematem dość burzliwych dyskusji prowadzonych w środowisku tłumaczy i jak na ten moment nie udało się wypracować żadnego konsensusu, w jaki sposób zapewnić rzetelną obsługę tłumaczeniową oraz w jaki sposób zleceniodawca - niezależnie od tego, czy jest nim sąd czy klient prywatny - mógłby weryfikować kwalifikacje tłumacza przed powierzeniem mu określonego zlecenia. Błędy w tłumaczeniu mogą pociągać za sobą różne skutki - od skutków marketingowych, przez finansowe i prawne (błędy w dokumentacji finansowej i tekstach prawnych i prawniczych), aż po zdrowotne (błędy w tłumaczeniu dokumentacji medycznej lub technicznej). Uwzględniając wcześniejsze rozważania, nieprawidłowe tłumaczenie zeznań świadków może mieć wpływ na orzeczenie sądu, które wprost przekłada się na życie stron (powoda lub pozwanego; oskarżonego lub pokrzywdzonego). Biorąc pod uwagę, jak złożonym procesem jest ocena wiarygodności zeznań oraz fakt, że strategia thumaczenia może w określony sposób wpływać na odbiór i ocenę jednego z kluczowych dowodów w sprawie - dowodu osobowego, wydaje się, że przygotowanie i kształcenie ustawiczne tłumaczy powinno obejmować również wpływu kwestię jakości tłumaczenia i zachowania tłumacza na zeznania świadka.

Artur Kubacki zwraca uwagę, że dopiero w Ustawie z dnia 25 listopada 2004 roku o zawodzie thumacza przysięgłego tłumacz uzyskał rangę niezależnego zawodu. Ustawa ta określa również sposób, jaki wymagania musi spełnić kandydat na tłumacza przysięgłego, jak przebiega proces nadawania uprawnień oraz jaka jest odpowiedzialność tłumacza (Kubacki 2014: 51). Kandydat na tłumacza przysięgłego, po zdaniu egzaminu, zostaje zaprzysiężony przez Ministra Sprawiedliwości, co w zasadzie uważa się za warunek wystarczający i konieczny do tego, aby wykonywane przez niego tłumaczenia uznać za wierne i rzetelne. Jak pokazuje życie - niekoniecznie tak jest, jednak kontrola nad tłumaczami jest znikoma pomimo działalności Komisji Odpowiedzialności Zawodowej działającej przy Ministerstwie 
Sprawiedliwości. Zasadnicza kontrola działalności tłumaczy, jaką sprawują wojewodowie, obejmuje zaledwie sposób prowadzenia repertorium i zgodność pobranych wynagrodzeń rozporządzeniem w sprawie wynagrodzenia za czynności tłumacza przysięgłego, a w ograniczonym zakresie samych czynności (Ostaszewski, Włodarczyk-Madejska 2016: 9).

Warto również nadmienić, że bardzo długo jedynym śladem posiedzenia sądu był protokół sporządzany przez sąd w trakcie rozprawy. Od 2014 roku, na mocy nowelizacji Kodeksu postępowania cywilnego, wprowadzono rejestrację rozpraw (nagrywanie obrazu i dźwięku), co umożliwia odtworzenie zeznań, a tym samym tłumaczenia. Nagrywanie rozpraw w procesach karnych wprowadzono dopiero w 2016 roku (na mocy nowelizacji Kodeksu postępowania karnego), jednak można z niego zrezygnować w dwóch przypadkach: 1) ze względu na ograniczenia techniczne, oraz 2) ze względu na wyłączenie jawności. Jak pokazuje praktyka, niewiele sądów rejestruje rozprawy. Przykładowo w Sądzie Okręgowym w Krakowie nagrywanie rozpraw w ogóle nie jest praktykowane w żadnym z wydziałów, zaś w krakowskich sądach rejonowych rozprawy nagrywane są na wniosek stron lub w przypadku, gdy istnieją ku temu stosowne przesłanki (1. zachodzi niebezpieczeństwo, że przesłuchanie tej osoby nie będzie możliwe $\mathrm{w}$ dalszym postępowaniu; 2. przesłuchanie następuje w trybie określonym $\mathrm{w}$ art. 396 - art. $147 \S 1$ k.k.).

\section{2) Współpraca z sądem}

Respondenci wskazali również na problemy, z jakimi borykają się tłumacze we współpracy z sądem. Sędziowie często nie potrafią się odnaleźć w sytuacji, w której nie mogą przesłuchać świadka bezpośrednio, a cała komunikacja ,przechodzi” przez tłumacza - to nierzadko powoduje ich irytację i zniecierpliwienie, które skutkuje pospieszaniem tłumacza, żądaniem, aby skracał tłumaczenie, podawał wyłącznie „najważniejsze” fakty, stawiając go tym samym w roli cenzora, który musi ad hoc stworzyć subiektywne résumé najważniejszych informacji z pominięciem innych danych. Problem nasila się $\mathrm{W}$ momencie, gdy świadek jest niezdyscyplinowany i nie odpowiada na pytania sądu.

Przeprowadzone dotychczas badania pokazują, że oczekiwania sędziów względem tłumaczy są niespójne. Część z nich wymaga, aby tłumacz zaledwie streszczał wypowiedź i upraszczał ją, pozostali zaś, oprócz pełnego thumaczenia, oczekują również wyjaśniania niuansów dyskursu prawniczego czy różnic kulturowych (zob. Pöchhacker 2001 lub Mendel 2011). 


\section{Wnioski}

Zadaniem tłumacza środowiskowego jest przekładanie zarówno treści („co”), jak i formy (,jak”), czyli całokształtu komunikatu z wszelkimi jego mankamentami, takimi jak powtórzenia, błędy, chaotyczny układ, specyficzny styl nadawcy, zająknięcia, niedopowiedzenia, itp. Jednak, jak podkreśla Małgorzata Tryuk, jest to wyidealizowany obraz pracy tłumacza, który dalece odbiega od praktyki (Tryuk 2006: 79). Jak pokazują przeprowadzone dotychczas badania, thumacze nie tylko nie dbają o detale w skali mikro, ale zdarza im się również ingerować w wypowiedź na poziomie makro: zmieniają rejestr stylistyczny, usuwają niedoskonałości wypowiedzi źródłowej, osadzają słowa nadawcy w swoim własnym stylu, porządkują wypowiedź ${ }^{7}$. Dodatkowym czynnikiem, który może mieć wpływ na jakość pracy tłumacza, jest współpraca z sądem i oczekiwania sędziów względem tłumaczy, które są czasem niewłaściwe z punktu widzenia jakości i wierności tłumaczenia.

Jeżeli tłumacz może w jakikolwiek sposób wpłynąć na ocenę wiarygodności zeznań, a tym samym - pośrednio - na orzeczenie sądu, wówczas pogłębione badania z wykorzystaniem psychologicznych i/albo prawniczych kryteriów oceny zeznań pozwoliłyby zidentyfikować konkretne problemy, z jakimi mamy do czynienia w przypadku tłumaczeń sądowych, co tym samym mogłoby się przełożyć na sposób szkolenia i przygotowania tłumaczy, ale także weryfikację ich kompetencji i jakości wykonywanej pracy. Niezwykle istotna wydaje się być także kwestia współpracy z sądami, której reguły powinny być jasno ustalone i znane zarówno sędziom, jak i thumaczom.

\footnotetext{
${ }^{1}$ Prawdziwość oznacza zgodność zeznania ze stanem obiektywnym, zaś szczerość subiektywne przekonanie świadka co do prawdziwości składanych zeznań. W ujęciu prawniczym zeznania można podzielić na osiem kategorii pod względem prawdziwości, szczerości i wiarygodności (zob. Wojciechowski 2016: 30).

${ }^{2}$ Rolę świadka w procesie cywilny reguluje Oddział 3 Kodeksu postępowania cywilnego.

${ }^{3} \mathrm{~W}$ rzeczywistości SVA obejmuje 9 kroków: 1) analiza akt sprawy, 2) formułowanie hipotez na temat źródła relacji świadka, 3) ustalenie płaszczyzn, które wymagają diagnozy psychologicznej oraz dobór metody,4) badanie świadka, które składa się z szczegółowego wywiadu, badania osobowości i zdolności poznawczych, jak również przesłuchanie świadka, 5) analiza treści zeznania z wykorzystaniem 19 kryteriów treściowych (Criteria-Based Content Analysis - CBCA), 6) ocena wyników analizy treściowej z uwzględnieniem: możliwości poznawczych świadka (jego sprawności językowej, kreatywności i poziomu inteligencji); wiedzy świadka i jego przeszłych doświadczeń; charakterystyki i właściwości zdarzenia, które jest przedmiotem postępowania, 7) analiza spójności wszystkich złożonych zeznań, 8) analiza źródła zeznania, która obejmuje między innymi: okoliczności ujawnienia czynu, reakcje innych osób na ujawnienie przestępstwa czy wcześniejsze przesłuchania, 9) weryfikacja hipotez sformułowanych na drugim etapie postępowania (Wojciechowski 2016: 53 i nast.).

${ }^{4}$ Technika została szczegółowo omówiona w monografii. Wojciechowskiego (2016).

${ }^{5}$ Podkreślenia autorki.

${ }^{6}$ Podkreślenia autorki.

${ }^{7}$ Warto nadmienić, że czyni to również sąd, stąd tak trudno jest w polskim warunkach pozyskać materiał do badań naturalnych, gdyż protokoły zeznan świadków sporządzone w czasie rozprawy istotnie różnią się od tego, co faktycznie zeznał świadek.
} 


\section{Bibliografia}

Amado, Barbara G., Ramon Arce, Francisca Farina, Manuel Vilarino (2016) „Criteria-Based Content Analysis (CBCA) Reality Criteria in Adults: A Meta-Analytic Review”. International Journal of Clinical and Health Psychology. [Pobrane z http://www.elsevier.es/es-revista-international-journal-clinical-health-psychology-355articulo-criteria-based-content-analysis-cbca-reality-S1697260016000041. Data ostatniego dostępu: 30.04 2016].

Berk-Seligson, Susan (1990) The Bilingual Courtroom. Court Interpreters in the Judicial Process. Chicago: University of Chicago Press.

Buchard, Maria (2009) „Ocena wiarygodności dowodu z przesłuchania poznawczego w procesie karnym". Acta Universitatis Wratislaviensis, Nr 3128; 175-180.

Gadomska-Radel, Anna (2010) „Ocena wiarygodności zeznań dzieci”. Prokuratura i Prawo $11 ; 77-95$.

Gruza, Ewa (2014) „Kryteria oceny wiarygodności zeznań dzieci”. Dziecko krzywdzone. Teoria, badania i praktyka, Vol. 13; 59-72.

Hale, Sandra (2004) The Discourse of Court Interpreting. Discourse Practices of the Law, the Witness and the Interpreter. Amsterdam/Philadelphia: John Benjamins Publishing Company.

Hale, Sandra (1997) „The Interpreter on Trial: Pragmatics in Court Interpreting”. [W:] Silcana E. Carr, Roda P. Roberts, Aideen Dufour, Dini Steyn (red.), The Critical Link: Interpreters in the Community. Amsterdam: John Benjamins Publishing Company; $201-211$.

Köhnken, Gönter, Elke Schimossek, Ellen Aschermann, Eberhard Höfera (1995) „The Cognitive Interview and the Assessment of the Credibility of Adults' Statements". Journal of Applied Psychology, Vol. 80, No 6; 671-684.

Kubacki, D. Artur (2014) “Tłumacz przysięgły w polskim systemie wymiaru sprawiedliwości”. Kwartalnik Krajowej Szkoty Sadownictwa i Prokuratury, zeszyt 4. [Pobrane z http://www.kwp.radom.pl/media/przeglady/pdf/kssip-kwartalnik-numer-4-152014_18259.pdf._Data ostatniego dostępu: 02.05.2017].

Liber, Katarzyna (2017) “Trafność diagnostyczna dodatkowych kryteriów 'Criteria-Based Content Analysis"”. [W:] Bartosz W. Wojciechowski (red.) Zeznania i wyjaśnienia: badania nad ocena i psychologicznymi uwarunkowaniami. Warszawa: Difin; 221-237.

Ludwin, Iwona (2015) Świadek w procesie karnym. [Pobrane z: www.wspia.eu/file/21411/15LUDWIN.pdfc. Data ostatniego dostępu 15.02.2017]. 
Maciaszek, Patrycja (2013) „Fałszywe wspomnienia: jak to się dzieje, że umysł pamięta coś, czego nie było". Przeglad Filozoficzny - Nowa Seria Nr 2 (86); 305-321.

Maciejski, Marcin (2009) Psychologiczna analiza sposobów przesłuchania świadków i reguł oceny ich zeznań w praktyce sędziowskiej a stopień przypisywanej im wiarygodności. [Niepublikowana praca doktorska]: Uniwersytet Śląski.

Maciejski, Marcin (2015), Reguły sędziowskiej oceny wiarygodności zeznań świadków”. [W:] Bartosz W. Wojciechowski (red.) Psychologiczne uwarunkowania i ocena wartości dowodowej zeznań. Warszawa: Difin; 176-211.

Marten, Zbigniew (1990) Wstęp do psychologii sądowej. Katowice: Wydawnictwo UŚ.

Mason, Ian, Miranda Stewart (2001) „Interactional Pragmatics, Face and the Dialogue Interpreter". [W:] Ian Mason (red.) Triadic Exchanges: Studies in Dialogue Interpreting. London/New York: Routledge, 51-70.

Mendel, Anna (2011) Raport z badania ankietowego na temat jakości thumaczenia $w$ postępowaniu karnym. [Pobrane z https://www.kssip.gov.pl/sites/default/files/18_8.pdf. Data ostatniego dostępu 15.02.2017].

Najder, Krzysztof (1992) „Wprowadzenie do teorii pamięci”. [W:] Maria Materska, Tadeusz Tyszka (red.) Psychologia i poznanie. Warszawa: PWN; 126-160.

Niezgoda, Zbigniew (2007) „Kryminalistyczne aspekty przesłuchania świadka”. Prokuratura $i$ Prawo 2; 76-86.

Ostaszewski, Paweł, Justyna Włodarczyk-Madejska (2016) Tłumaczenia poświadczone w praktyce wymiaru sprawiedliwości. Warszawa: Instytut Wymiaru Sprawiedliwości. [https://www.iws.org.pl/pliki/files/IWS_Ostaszewski\%20P.\%20W\%C5\%82odarczykMadejska\%20J._T\%C5\%82umaczenia\%20po\%C5\%9Bwiadczone.pdf. Data ostatniego dostępu: 15.05.2017].

Pieszko-Sroka, Anna (2011) „Czy zeznania są wiarygodne? Poszukiwanie metody ich oceny i rola psychologa w tym procesie”. Przegląd Bezpieczeństwa Wewnętrznego Nr 5; 44-54.

Płachta, Michał (1984) „Wiarygodność zeznań świadka. Niektóre problemy logiczne”. Ruch prawniczy, ekonomiczny i socjologiczny Rok XLVI - Zeszyt 2; 157-169.

Pöchhacker, Franz (2011) „Quality Assessment in Conference and Community Interpreting”. Meta XLVI 2; 410-415.

Stawiarski, Arkadiusz (2008) Czynniki wptywające na wiarygodność zeznań świadków wybrane zagadnienia. [Pobrane z: http://katowice.szkolapolicji.gov.pl/wp- 
content/uploads/2010/08/czynniki_wplywajace_na_wiarygodnosc_zeznan_swiadkow.pdf Data ostatniego dostępu 15.10. 2016].

Tryuk, Małgorzata (2006) Przekład ustny środowiskowy. Warszawa: PWN.

Vrij, Aldert (2009) Wykrywanie kłamstw i oszukiwania. Psychologia kłamania i konsekwencje dla praktyki zawodowej. Kraków: Wydawnictwo Uniwersytetu Jagiellońskiego.

Wojciechowski, Bartosz W. (2016) Analiza i ocena zeznań świadków. Sopot: GWP.

Wojciechowski Bartosz W. (2014) „Psychologiczna analiza treści zeznań“. Acta Universitatis Lodziensis, Folia Psychologica, 18; 85-109. 